\title{
Review
}

\section{Greenhouse gas mitigation options in Brazil for land-use change, livestock and agriculture}

\author{
Carlos Clemente Cerri ${ }^{1}$; Martial Bernoux²; Stoecio Malta Ferreira Maia ${ }^{1}$; Carlos Eduardo \\ Pellegrino Cerri ${ }^{3 *}$; Ciniro Costa Junior ${ }^{1}$; Brigitte Josefine Feig ${ }^{1}$; Leidivan Almeida Frazão \\ Francisco Fujita de Castro Mello ${ }^{5}$; Marcelo Valadares Galdos'; Cindy Silva Moreira ${ }^{5}$; \\ João Luis Nunes Carvalho ${ }^{4}$ \\ ${ }_{2}^{1}$ USP/CENA - Lab. de Biogeoquímica Ambiental, Av. Centenário, 303 - 13400-970 - Piracicaba, SP - Brasil. \\ 'Institut de Recherche pour le Développement - IRD, UMR EcoESols "Functional Ecology E Soil Biogeochemistry" \\ (INRA-IRD-SupAgro), Bat. 12, 2 Place Viala, 34060 - Montpellier Cedex 1 - France. \\ ${ }^{3}$ USP/ESALQ - Depto. de Ciência do Solo, C.P. 09 - 13418-900 - Piracicaba, SP - Brasil. \\ ${ }^{4}$ USP/ESALQ - Programa de Pós-Graduação em Solos e Nutrição de Plantas. \\ 'USP/CENA - Programa de Pós-Graduação em Ciências. \\ *Corresponding author <cepcerri@esalq.usp.br>
}

ABSTRACT: National inventories of anthropogenic greenhouse gas (GHG) emissions (implementation of the National Communications) are organized according to five main sectors, namely: Energy, Industrial Processes, Agriculture, Land-Use Change and Forestry (LUCF) and Waste. The objective of this study was to review and calculate the potential of greenhouse gas mitigation strategies in Brazil for the Agricultural and LUCF. The first step consisted in an analysis of Brazilian official and unofficial documents related to climate change and mitigation policies. Secondly, business as usual (BAU) and mitigation scenarios were elaborated for the 2010-2020 timeframe, and calculations of the corresponding associated GHG emissions and removals were performed. Additionally, two complementary approaches were used to point out and quantify the main mitigation options: a) following the IPCC 1996 guidelines and b) based on EX-ACT. Brazilian authorities announced that the country will target a reduction in its GHG between 36.1 and $38.9 \%$ from projected 2020 levels. This is a positive stand that should also be adopted by other developing countries. To reach this government goal, agriculture and livestock sectors must contribute with an emission reduction of 133 to $166 \mathrm{Mt} \mathrm{CO}_{2}$-eq. This seems to be reachable when confronted to our mitigation option values, which are in between the range of 178.3 to $445 \mathrm{Mt}$ $\mathrm{CO}_{2}$-eq. Government investments on agriculture are necessary to minimize the efforts from the sectors to reach their targets.

Key words: IPCC, EX-ACT, emission reduction, carbon fixation

\section{Opções de mitigação de gases do efeito estufa na mudança do uso da terra, pecuária e agricultura no Brasil}

RESUMO: Inventários nacionais acerca de emissões de gases do efeito estufa (GEE) (refinamentos das Comunicações Nacionais) são organizadas de acordo com cinco principais setores, a saber: Energia, Processos Industriais, Agropecuária, Mudanças do Uso da Terra e Florestas e Tratamento de Resíduos. O objetivo dessa revisão foi calcular o potencial das estratégias de mitigação de GEE no Brasil para agropecuária e mudança de uso da terra e florestas. A primeira etapa consistiu na análise de documentos oficiais e nãooficiais do Brasil relacionados a mudanças climáticas e políticas de mitigação. O cenário atual, sem adoção de ações mitigadoras (BAU), e os cenários de mitigação foram elaborados para o período 2010-2020. Efetuaram-se os cálculos associados às emissões e remoções de GEE. Adicionalmente, duas estratégias foram utilizadas para destacar e quantificar as principais opções de mitigação: a) seguindo metodologia do IPCC 1996 e b) baseando-se no EX-ACT. Autoridades brasileiras anunciaram que o país buscará reduzir sua taxa de emissão de GEE em 36.1 a 38.9\% em relação a 2020. Este é um posicionamento positivo que deve ser adotado por outros países em desenvolvimento. Para alcançar essa meta governamental, os setores agricultura e pecuária devem contribuir reduzindo a emissão em 133 a 166 Mt CO _eq. Tal redução parece ser atingível quando confrontada com os valores do presente trabalho sobre opções de mitigação os quais estão entre 178,3 e $445 \mathrm{Mt} \mathrm{CO}$-eq. Investimentos governamentais nos setores agrícola, pecuária e silvicultura são necessários para minimizar os esforços para atingir as metas de redução de emissão pelos outros setores do país.

Palavras-chave: IPCC, EX-ACT, redução de emissão, sequestro de carbono 


\section{Introduction}

The United Nations Framework Convention on Climate Change (UNFCCC) requires countries to develop, update and publish their national inventories of anthropogenic greenhouse gas (GHG) emissions (implementation of the National Communications). Those inventories are organized according to five main sectors, namely: Energy, Industrial Processes, Agriculture, Land-Use Change and Forestry (LUCF) and Waste.

The Intergovernmental Panel on Climate Change (IPCC) detailed methodologies, good practice guidance and guidelines were followed. Data for the 1990-1994 period were reported in Brazil's Initial National Communication and were recently updated for 2000 and 2005 by Cerri et al. (2009). The authors calculated that the top four contributors in Brazil in 2005 were responsible for $90 \%$ of the total emitted in $\mathrm{CO}_{2}$-equivalent $\left(\mathrm{CO}_{2}\right.$-eq) from all sectors considering $\mathrm{CO}_{2}, \mathrm{~N}_{2} \mathrm{O}$ and $\mathrm{CH}_{4}$. The largest contributor was the "Forest and Grassland Conversion" subsector of the LUCF Sector (1,074.2 $\mathrm{Mt} \mathrm{CO}_{2}^{-}$ eq) followed by the "Fossil Fuel Combustion" subsector (374.0 Mt $\mathrm{CO}_{2}$-eq) of the Energy sector. The third and fourth largest contributors belong to the Agriculture sector, being respectively the "Enteric Fermentation" (248.4 Mt CO -eq) and the "Agricultural Soils" subsectors (192.9 $\mathrm{Mt} \mathrm{CO}_{2}$-eq). Major individual emitting sectors or subsectors offer the largest mitigation potentials (IPCC, 2007). Therefore, the LUCF and Agriculture sectors are of great importance to mitigate GHG emissions.

Furthermore, they emit both $\mathrm{CO}_{2}$ and non- $\mathrm{CO}_{2}$ GHG $\left(\mathrm{N}_{2} \mathrm{O}\right.$ and $\left.\mathrm{CH}_{4}\right)$, which also have large implications at the global scale. For instance, Brazil and India are among the five largest emitters of non-CO, GHG. Globally, $\mathrm{CH}_{4}$ and $\mathrm{N}_{2} \mathrm{O}$ emissions from agricultural activities are projected to increase in the range of $20-40 \%$, mainly for agricultural soil $\mathrm{N}_{2} \mathrm{O}$ emissions, enteric emissions, paddy rice, and manure management (USEPA, 2006). All those considerations highlight that mitigating GHG emissions is a great challenge for Brazil itself, but with worldwide importance. Concomitantly with the emissions, Agriculture and LUCF are also able to remove $\mathrm{CO}_{2}$ from the atmosphere depending on the land conversion (e.g., abandonment of managed lands) and management (Bernoux et al., 2001, 2006; Cerri et al., 2004, 2007). Thus, the objective of this study is to review and calculate the potential of mitigation strategies (decreasing emissions and enhancing sinks) in Brazil for the Agricultural and LUCF sectors, both considering already foreseen strategies and proposing new options.

\section{Methodology}

The first step consisted in an analysis of official and unofficial documents dealing with proposed climate change and mitigation specific policies for Brazil or concerning land-use and management options largely adopted in Brazil. In a second step, business as usual (BAU) and mitigation scenarios were elaborated for the
2010-2020 timeframe, and calculations of the corresponding associated GHG emissions were performed.

Secondly, two complementary approaches were used to review and quantify mitigation options. Under the first approach, calculations followed the proposal of the revised 1996 Guidelines for National Greenhouse Gas Inventories (IPCC, 1997). The estimates were done separately for each option (BAU or mitigation scenarios) using detailed calculation steps. For this purpose, we also used specific methodologies or an adaptation for Brazil of the IPCC Guidelines provided in the background reports established for Brazil's Initial National Communication (BINC) purpose (the reports are available at http:/ /www.mct.gov.br/index.php/content/view/20233.html). Five of those reports concerned the Agriculture and Livestock sector, and four others were related to the LUCF sectors. Each report provides in detail the data sources and the steps followed in the calculation, thus enabling the use of exactly the same methodology.

The second approach was based on EX-ante Appraisal Carbon-balance Tools (EX-ACT, Bernoux et al., 2010). EX-ACT is a tool developed by the Food and Agriculture Organization of the United Nations (FAO) to provide ex-ante measurements of the impact of agriculture and forestry development projects on GHG emissions and Carbon (C) sequestration, indicating their effects on the $\mathrm{C}$ balance. EX-ACT is a land-based accounting system, measuring $\mathrm{C}$ stocks, stock changes per unit of land, and $\mathrm{CH}_{4}$ and $\mathrm{N}_{2} \mathrm{O}$ emissions expressed in $\mathrm{Mt} \mathrm{CO}_{2}-\mathrm{eq} \mathrm{ha}^{-1} \mathrm{yr}^{-1}$. The main output of the tool consists of the C-balance resulting from the difference between two scenarios, generally a newly proposed option and the BAU option.

EX-ACT was designed to work at the project level, but it can easily be up-scaled to the program/sector or national levels. EX-ACT has been developed using mostly the 2006 Guidelines for National Greenhouse Gas Inventories (IPCC, 2006) complemented with other existing methodologies or default coefficients. Default values for mitigation options in the agriculture sector are mostly from IPCC (2007). Therefore, EX-ACT does not use quite the same coefficients and methodology as those described in the Revised 1996 Guidelines for National Greenhouse Gas inventories. For instance, the C changes due to land management in EX-ACT are based on a coefficient relating $\mathrm{C}$ variation per year, whereas the 1996 guidelines considered a C stock change over a period of 20 years based on $\mathrm{C}$ stocks before and after the adoption of new practices. Besides, in EX-ACT the land accounting must be identical with and without the mitigation options; this is obtained through the construction of a matrix of changes.

\section{Mitigation potentials for the LUCF sector}

\section{Avoided Deforestation}

Since deforestation is responsible for more than half of the Brazilian GHG emissions, this sector has received much attention from national political authorities at all levels, non-governmental organizations, and various 
other national and international stakeholders. In November 2007, the Brazilian Federal government adopted a regulation (Decree $n^{\circ} 6263$ of November 21, 2007) establishing the Inter-Ministerial Committee on Climate Change and the elaboration of the National Plan on Climate Change (NPCC). This document (Brasil, 2008a) proposes a scenario (named here as "Committed Mitigation") of consistent reduction in the deforestation rate for the Amazon region over quadrennial periods: Reduction of $40 \%$ on average in the first quadrennial (2006$2009)$ in relation to the $1996-2005$ average rate $\left(19,533 \mathrm{~km}^{2}\right.$ $\mathrm{yr}^{-1}$, named here BAU scenario NPCC option), i.e. a mean deforestation rate of $11,720 \mathrm{~km}^{2} \mathrm{yr}^{-1}$ for the 20062009 period. This is followed by subsequent reduction of $30 \%$ on average, i.e., a mean deforestation rate of 8,204 $\mathrm{km}^{2} \mathrm{yr}^{-1}$ for the 2010-2013 period, and again a subsequent reduction of 30\% in 2014-2017 reaching a mean deforestation rate of $5,743 \mathrm{~km}^{2} \mathrm{yr}^{-1}$. More recently ( $1^{\text {st }}$ of June 2009) the Brazilian President Luiz Inácio Lula da Silva declared that the reduction should reach $80 \%$ in 2020 , i.e. establishing the new deforestation rate to $3,907 \mathrm{~km}^{2}$ $\mathrm{yr}^{-1}$. This will correspond roughly to the Scenario from the NPCC with one more quadrennial reduction of $30 \%$, i.e. $4,020 \mathrm{~km} \mathrm{yr}^{-1}$ (Figure 1).

In addition to the "BAU - NPCC option" scenario, we considered an alternative BAU scenario, "BAU Standby option", assuming that annual deforestation rates will be on average $10,000 \mathrm{~km}^{2}$, roughly corresponding to the average of the last two years. The latest deforestation rate for 2009 was estimated at $7,009 \mathrm{~km}^{2} \mathrm{yr}^{-1}$. Therefore, the average rate for the 2006-2009 period would be below $12,185 \mathrm{~km}^{2} \mathrm{yr}^{-1}$, i.e. very close to the rate forecasted in the NPCC. In addition to this scenario, two other scenarios were considered starting from 2010, one with higher reduction (High Mitigation) rate of nearly $50 \%$ each quadrennial, with $5,884 \mathrm{~km}^{2} \mathrm{yr}^{-1}$ in $2010-2013$, $2,942 \mathrm{~km}^{2} \mathrm{yr}^{-1}$ in 2014-2017 and 1,471 in 2018-2021, and another less intensive one with only a $15 \%$ of reduction (Low Mitigation) in each quadrennial.
The same scenarios (Committed, High and Low Mitigation) were considered for the other Brazilian biomes: Cerrado, Caatinga, Pantanal and Atlantic forest (as in the BINC, Pampas areas were not considered in this calculation). However, due to difficulties in having good estimates of the deforestation rates for the 1995-2005 period, the BAU scenarios considered the last available rates and assumed they are also valid until 2009. The "BAU Standby option" includes rates of 21,260; 1,521; 1,633 and $341 \mathrm{~km}^{2} \mathrm{yr}^{-1}$ for the Cerrado, Caatinga, Pantanal and Atlantic forest, respectively.

Figure 2 illustrates the observed emissions till 2009 and the patterns of the two different BAU options and the mitigation scenarios. EX-ACT (Bernoux et al., 2010) calculations were performed on the BAU-NPCC option compared to Mitigation Committed scenario. In first step, default values and categories proposed by EX-ACT were used according to the ecological zones. The Amazon was considered as tropical rain forest, the Caatinga as tropical dry forest and all the other forest biomes (Cerrado, Atlantic Forest and Pantanal) were pooled together as tropical deciduous forest.

The dominant soil type was set as a low activity clay soil as this category describes most of the Brazilian soils (Bernoux et al., 2002). EX-ACT estimated the total emission for the 2010-2020 period in 26,666 $\mathrm{Mt} \mathrm{CO}_{2}$-eq and $8,420 \mathrm{Mt} \mathrm{CO}_{2}$-eq respectively for the BAU and Mitigation-committed scenarios. In a second step, EX-ACT was used with $\mathrm{C}$ stocks considered in the BINC for aboveground vegetation within each biome (e.g. $98.8 \mathrm{Mg} \mathrm{C}^{-} \mathrm{C}^{-}$ ${ }^{1}$ in the Amazon). This approach produced lower estimates with respectively 11,998 and 3,789 $\mathrm{Mt} \mathrm{CO}_{2}$-eq, very close to the results based on BINC methodology (Table 1). The difference is mainly due to three factors: EXACT considers higher above-ground biomass, BINC does not take below-ground biomass and litter variations into account, and EX-ACT also considers soil C stocks variation. Regarding this last point, this compartment is included in the "emissions and removals of $\mathrm{CO}_{2}$ by

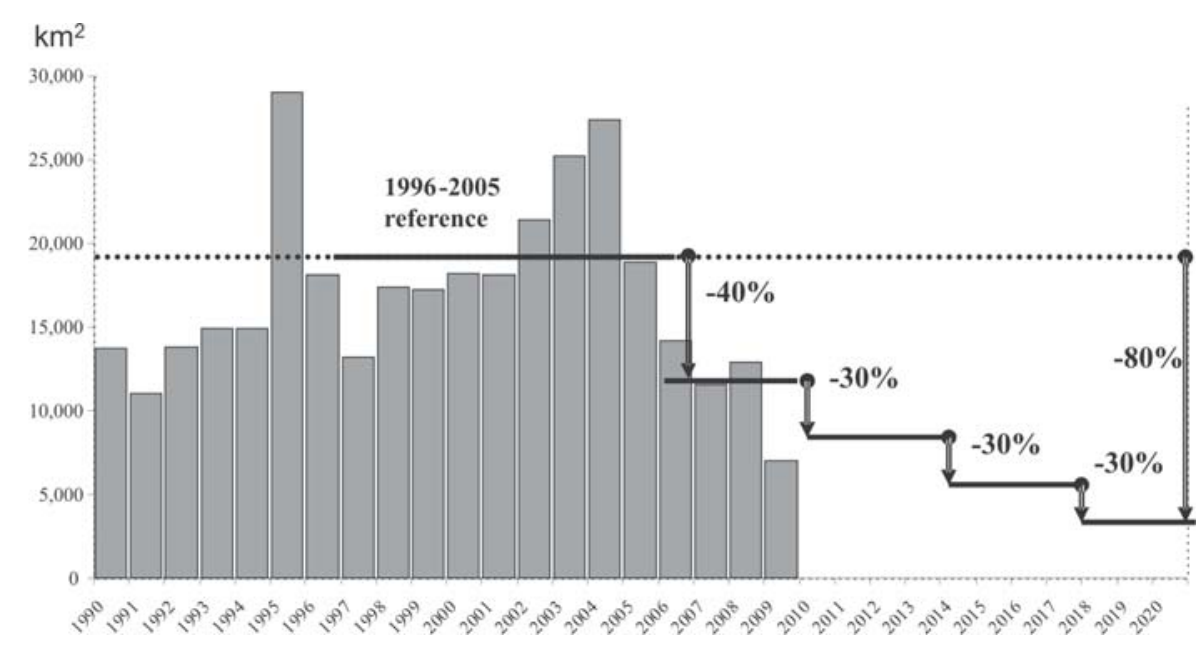

Figure 1 - Reported deforestation rates (bars), in the Amazon and levels of reduction (lines) by quadrennials proposed by the National Plan on Climate Change (Brasil, 2008a) in reference to the 1996-2005 baseline. 
soils" sub-sector in the BINC. Therefore, between 2010 and 2020, the avoided GHG emissions due to avoided deforestation in the Brazilian biomes can range from $8,240 \mathrm{Mt} \mathrm{CO}_{2}$-eq when only the above-ground biomass derived from the BINC defaults are considered, to 18,246

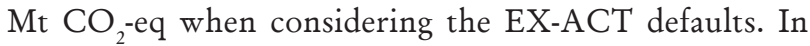
this case, this figure included the avoided emissions from below-ground biomass and litter.

\section{Afforestation/reforestation}

The planted forests in Brazil were evaluated to cover circa 6.6 Million hectares (Mha) in 2008 (ABRAF, 2009). Eucalyptus species represent alone nearly two thirds of the total with 4.2 Mha, followed by pine (Pinus spp) covering 1.9 Mha. The difference, about 456,700 ha, is dis-

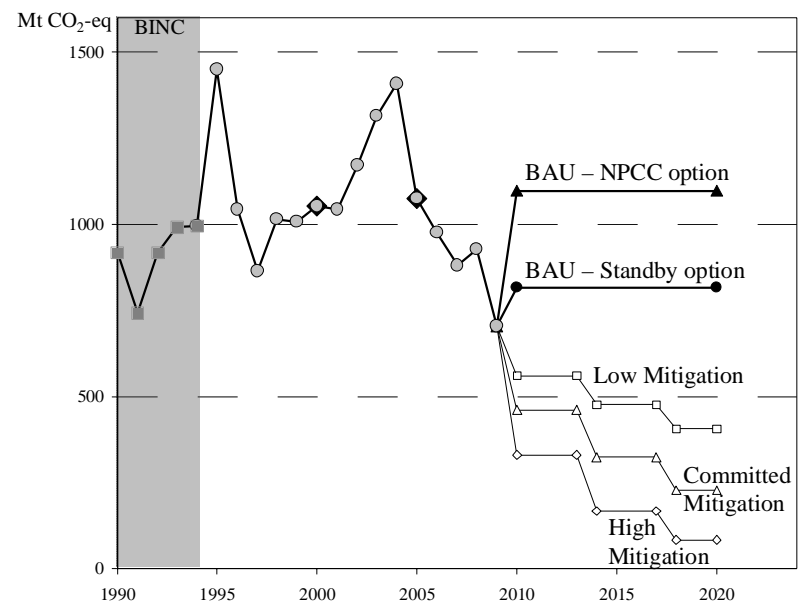

Figure 2 - Emissions associated with Land-Use Change: calculated according to available information and forecasted under different options with or without mitigation scenarios (Grey squares $(\square)$ refer to data published in the BINC (Brazil's Initial National Communication), grey circles $(\bullet)$ refer to recalculated emissions based on available deforestation rates or assumptions, and diamonds $(\checkmark)$ refer to values calculated by Cerri et al. (2009). BAU: Business as Usual; NPCC: National Plan on Climate Change; Standby: assuming that annual deforestation rates will be on average $10,000 \mathrm{~km}^{2}$. tributed among other species, mainly wattle (Accacia spp), Rubber trees (Hevea brasiliensis), Paricá (Schizolobium amazonicum) and Teak (Tectona grandis). Pine plantations are concentrated in the South Region (77\% of the total in 2008), while Southeast Region has $57 \%$ of the eucalyptus area in the country. The State of Minas Gerais has the largest combined eucalyptus and pine planted area in Brazil in 2008, with 1,423,212 ha, followed by São Paulo state with 1,142,199 ha (ABRAF, 2009).

Since 2004, the planted area with eucalyptus showed a mean annual increase of $7.4 \%$, an average of 265,000 additional ha per year. In the same period, the pine area increased by $1.4 \%$ per year, an average of 26,000 ha per year. The area occupied by other species was rather stable between 2007 and 2008 (ABRAF 2009), while it increased 2.9\% in 2007 (ABRAF, 2008) and 1.4\% in 2006 (ABRAF, 2007) in comparison to the previous year. Thus, a Plantation-BAU scenario was set up using these annual increments.

An additional scenario (NPCC-scenario) was made considering the Brazilian government proposition (Brasil, 2008b) of doubling the area of planted forests (apparently considering 2005 values), implanting another 5.5 million ha until 2020 (including 2 Mha of native species); that proposition follows the pattern of $75 \%$ with eucalyptus and $20 \%$ with pine (ABRAF, 2009). These new plantations are expected to be located on degraded pastures.

In addition to biomass and soil $\mathrm{C}$ stock changes (BINC), emissions associated with plantation management were computed, including $\mathrm{N}$ fertilizer application, liming and fossil fuel use in machinery operations, based on scientific and technical reports (Gonçalves, 1995; Mafra et al., 2008; VPC, 2008; unpublished data from C.S. Moreira). Table 2 detailed the different contributions in the final balance for the Plantation-NPCC scenario.

The eucalyptus and pine participation on the mitigation scenarios were around $75 \%$ and $25 \%$, respectively. And the above and below ground biomass is the component evaluated with the highest potential for $\mathrm{C}$ input, while lime and fossil fuel are the major $\mathrm{C}$ outputs. When comparing the corresponding areas under

Table 1 - Total and average GHG emissions under the different avoided deforestation scenarios for different periods of time*

\begin{tabular}{|c|c|c|c|c|c|c|c|c|}
\hline \multirow{2}{*}{ Scenario } & \multicolumn{5}{|c|}{ Total over the period $\left(\mathrm{Mt} \mathrm{CO}_{2-\mathrm{eq}}\right)$} & \multicolumn{3}{|c|}{ Yearly average $\left(\mathrm{Mt} \mathrm{CO}_{2 \text {-eq }} \mathrm{yr}^{-1}\right)$} \\
\hline & $2010-2020$ & $2008-2012$ & $2013-2017$ & 2010 & 2020 & $2010-2020$ & $2008-2012$ & 2013-2017 \\
\hline \multicolumn{9}{|l|}{ BAU } \\
\hline NPCC & 12,048 & 4,918 & 5,476 & 1,095 & 1,095 & 1,095 & 984 & 1,095 \\
\hline Standby & 7,749 & 3,746 & 4,088 & 704 & 704 & 704 & 749 & 818 \\
\hline \multicolumn{9}{|l|}{ Mitigation } \\
\hline Low & 5,349 & 3,309 & 2,460 & 559 & 404 & 486 & 662 & 492 \\
\hline Committed & 3,808 & 3,013 & 1,750 & 460 & 226 & 346 & 603 & 350 \\
\hline High & 2,220 & 2,619 & 987 & 329 & 82 & 202 & 524 & 197 \\
\hline
\end{tabular}

*2008-2012 and 2013-2017 correspond respectively to the $1^{\text {st }}$ and $2^{\text {nd }}$ commitment periods under the Kyoto Protocol (even though Brazil is not subject to Quantified Emission Reductions, it is a useful comparison parameter). BAU: Business as Usual. NPCC: National Plan on Climate Change. Standby: assuming that annual deforestation rates will be on average $10,000 \mathrm{~km}^{2}$. 
Table 2 - Sinks and sources in $\mathrm{Mt} \mathrm{CO}_{2}$-eq associated with the eucalyptus and pine plantations according to the PlantationNPCC scenario.

\begin{tabular}{|c|c|c|c|c|c|c|c|}
\hline \multirow{2}{*}{ Source } & \multirow{2}{*}{ Year } & \multicolumn{2}{|c|}{ Eucalyptus } & \multicolumn{2}{|c|}{ Pine } & \multicolumn{2}{|c|}{ Total } \\
\hline & & Sink & Source & Sink & Source & Sink & Source \\
\hline \multirow{4}{*}{$\begin{array}{l}\text { Above and below } \\
\text { ground biomass }\end{array}$} & & $\ldots$ & 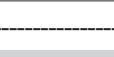 & 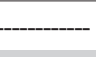 & $\mathrm{O}_{2 \text { eq }}$ & 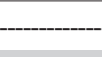 & 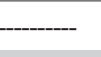 \\
\hline & 2010 & 7.9 & - & 1.9 & - & 9.8 & - \\
\hline & 2015 & 52.4 & - & 12.8 & - & 65.2 & - \\
\hline & 2020 & 105.4 & - & 25.8 & - & 131.2 & - \\
\hline \multirow{3}{*}{ Soil } & 2010 & 0.5 & - & -0.1 & - & 0.4 & - \\
\hline & 2015 & 3.5 & - & -0.8 & - & 2.6 & - \\
\hline & 2020 & 7.0 & - & -1.6 & - & 5.3 & - \\
\hline \multirow{3}{*}{ Lime } & 2010 & - & 1.7 & - & 0.3 & - & 2.0 \\
\hline & 2015 & - & 2.1 & - & 0.4 & - & 2.5 \\
\hline & 2020 & - & 4.3 & - & 0.5 & - & 4.8 \\
\hline \multirow{3}{*}{ Nitrogen fertilizer } & 2010 & - & 0.1 & - & 0.0 & - & 0.1 \\
\hline & 2015 & - & 0.1 & - & 0.0 & - & 0.1 \\
\hline & 2020 & - & 0.2 & - & 0.0 & - & 0.2 \\
\hline \multirow{3}{*}{ Fossil fuel } & 2010 & - & 0.2 & - & 0.0 & - & 0.2 \\
\hline & 2015 & - & 0.2 & - & 0.1 & - & 0.3 \\
\hline & 2020 & - & 0.4 & - & 0.1 & - & 0.5 \\
\hline \multirow{3}{*}{ Annual balance } & 2010 & 6.5 & & 1.4 & & 7.9 & \\
\hline & 2015 & 53.5 & & 11.5 & & 65.0 & \\
\hline & 2020 & 107.5 & & 23.6 & & 131.1 & \\
\hline Net Balance & $2010-2020$ & 574.3 & & 130.9 & & 705.1 & \\
\hline
\end{tabular}

${ }^{1}$ BRAZIL (2004); ${ }^{2}$ Mafra et al. (2008) and Unpublished data from C.S. Moreira; ${ }^{3}$ Gonçalves, (1995); ${ }^{4} \mathrm{VCP}$ (2007). NPCC: National Plan on Climate Change.

BAU and NPCC in the $2010-2020$ period, the potential for mitigation of global warming by eucalyptus and pine was, respectively, 652.7 $\mathrm{Mt} \mathrm{CO}_{2}$-eq (BAU) and $705.1 \mathrm{Mt}$ $\mathrm{CO}_{2}$-eq (NPCC). It appeared that the final areas are similar, and therefore the Brazilian proposition is rather conservative, representing a modest mitigation effort of 52.4 $\mathrm{Mt} \mathrm{CO}_{2}$-eq. Thus, a more ambitious scenario was built, named Plantation-High. That scenario considers that in 2020 the planted area will reach 16.5 Mha, tripling the 2005 area. The results showed that the Plantation high scenario would almost be $1,000 \mathrm{Mt} \mathrm{CO}_{2}$-eq higher than $\mathrm{BAU}$ and NPCC scenarios in the period considered.

In terms of mean annual additional mitigation when in comparison to BAU, the Plantation-High scenario corresponds to a potential of $100 \mathrm{Mt} \mathrm{CO}_{2}$-eq $\mathrm{yr}^{-1}$, whereas the scenario proposed by the Brazilian government only 5.2 $\mathrm{Mt} \mathrm{CO}_{2}$-eq $\mathrm{yr}^{-1}$, becoming obviously more effective to C sequestration. EX-ACT (Bernoux et al., 2010) calculations were performed on the Plantation-High and Plantation-NPCC options and compared to the PlantationBAU scenario. Eucalyptus and pine plantations were both considered as "subtropical dry forest" plantation type implemented on degraded land. EX-ACT estimated that Plantation-High and Plantation-NPCC increase sink by, respectively, $1,322 \mathrm{Mt} \mathrm{CO}_{2}$-eq and $187 \mathrm{Mt} \mathrm{CO}_{2}$-eq in relation to BAU, i.e. results of the same order to the estimates above, but clearly using specific default values for eucalyptus and pine would improve the estimates.

\section{Mitigation potential for the livestock sector}

Globally, livestock enteric $\mathrm{CH}_{4}$ accounted for one third of global agricultural non- $\mathrm{CO}_{2}$ emissions in 2000 (USEPA, 2006). In Brazil, the Enteric Fermentation subsector was the third contributor to Brazilian GHG emissions in terms of $\mathrm{CO}_{2}$-eq (Cerri et al., 2009). It is also by far the first contributor for $\mathrm{CH}_{4}$ emission. Among the components, the non-dairy cattle were responsible for $82.2 \%$ of total enteric fermentation for the year 1994 . Cattle were also responsible for Agricultural soil sub-sector emissions, regarding $\mathrm{N}_{2} \mathrm{O}$ emissions from direct manure deposition on field by grazing animals. Grazing animals' contribution is $46 \%$ of the sub-sector, $34 \%$ of which is from non-dairy cattle. Cerri et al. (2009) showed that the emission due to enteric fermentation increased by $26.1 \%$ in 2005 in relation to 1994 , and represented $12 \%$ of the total Brazilian GHG emissions. At the global level, Brazilian cattle are also of prime importance. Brazil accounts for $20 \%$ of the meat production and $23.5 \%$ of the milk production in developing countries (FAO, 2006). Therefore, this section will focus only on cattle, although mitigation actions are certainly possible for other animals such as swine and poultry. 
The NPCC (Brasil, 2008a) did not detail mitigation strategies concerning livestock in general and cattle, specifically. It only stated that increasing the quality of pastures may reduce $\mathrm{CH}_{4}$ emission from cattle. Methane is produced during anaerobic fermentation of carbohydrates, mainly from grass forage. Anaerobic fermentation is the result from the digestive process of herbivore ruminants in the rumen. Methane emissions are impacted by a number of factors including the animal traits (e.g. age, bodyweight, and genetics), feed quality and environmental parameters (e.g. temperature). Therefore, mitigation options would have to address those drivers. IPCC (2007) reviewed the mitigation potentials linked mostly with animal and feed factors and reported that they could be categorized more precisely into improved feeding practices, use of specific agents or dietary additives, and longer term management changes and animal breeding.

Concerning feeding practices, IPCC (2007) showed that the use of more concentrates commonly increases $\mathrm{CH}_{4}$ emission on an animal basis, but since it also increases performance (milk and meat), the end result is an overall reduction of $\mathrm{CH}_{4}$ emissions per unit of product (litter of milk or kg of meat). Moreover, the enrichment of the diet with concentrates is more efficient with complementary practices related to management (e.g. younger age at slaughter for beef animals) or feeding (oil seeds' addition). Another alternative consists in the use of additives (ionophores, propionate precursors, condensed tannins) that directly affect methanogenesis inside the rumen, but these options may be limited due to existing barriers regarding their use (for instance, ionophores are banned in Europe market), their cost, or adverse effects in meat conversion rates. Choice of the animal might be of prime importance. Pedreira et al. (2009) showed that with the same diet and conditions, emissions per animal from lactating cows were higher for black and white Holstein than for Brazilian dairy Zebu crossbred, but concluded that Holstein cows may dilute $\mathrm{CH}_{4}$ emission per $\mathrm{kg}$ of milk due to their greater milk production. Demarchi et al. (2003) stated that a decrease in the average slaughter age of steers of Brazilian Nelore would decrease total methane emissions by $10 \%$ for the Brazilian beef cattle production system.

Manure management also emits $\mathrm{CH}_{4}$ and $\mathrm{N}_{2} \mathrm{O}$. These emissions are the result of microbial activities from nitrifiers and denitrifiers for $\mathrm{N}_{2} \mathrm{O}$ and methanogens for $\mathrm{CH}_{4}$. Thus emissions can be related with the temperature, more or less according to the type and form (liquid or solid) of manure management. Animal manure can be stored either wet (e.g. slurry) or dry (e.g. farm yard manure). Methane emissions occur mainly when the manure is managed in liquid forms (lagoon or holding tanks) or remain wet. Worldwide, intensive livestock systems commonly use liquid manure management due to the large quantity of manure produced and easier handling and collection with pipelines (Reid et al., 2004). In Brazil, most intensive livestock systems adopt the dry lot based systems.
The manure management is important in deriving emissions' coefficient. IPCC methodologies (IPCC, 2006) proposed coefficient of methane emission factors by temperature. For Latin America the coefficients are small and rather stable with temperature: $1 \mathrm{~kg} \mathrm{CH}_{4}$ head $^{-1} \mathrm{yr}^{-1}$ for cattle, buffalo and swine for mean annual temperature, except for dairy cattle where the value increases to $2 \mathrm{~kg} \mathrm{CH}_{4}$ head $\mathrm{yr}^{-1}$ above $25^{\circ} \mathrm{C}$. But this is the result of hypothesis regarding the manure management. IPCC assumes that for Latin America almost all (99\%) manure is left on pastures and rangeland for nondairy cattle. For dairy cattle, this management accounts for only $36 \%$, while $62 \%$ is managed as daily spread (i.e. removed from confinement facilities and applied to cropland or pasture within 24 hours of excretion). The remaining $2 \%$ is managed as half liquid/slurry (i.e. stored as excreted or with a minimal addition of water) or solid storage (i.e. storage for a period of several months in unconfined piles or stacks). The manure coefficient emission for lagoon and liquid/slurry are calculated based on the van't Hoff-Arrhenius equation linking temperature to biological activities (Mangino et al., 2001). A direct consequence is that any change towards more liquid/slurry of lagoon will sharply increase $\mathrm{CH}_{4}$ emissions, even more in warm regions. Thus, in any process of intensification or confinement of cattle, it will be important to promote the capture and use of $\mathrm{CH}_{4}$ through anaerobic digesters.

The calculation of emissions from enteric fermentation and manure management used the number of cattle head. Emissions from manure management calculated here correspond to the total of emissions reported under the categories "Manure management" and "Agricultural soils" subcategories (under the item "Grazing Animals") used in the BINC and Cerri et al. (2009). Concerning the forecasted evolution of the number of animals in Brazil, the NPCC (Brasil, 2008a) did not propose or review scenarios. Therefore, the BAU scenario was elaborated considering the statistics of the 1996-2005 timeframe, which corresponds to the last 10-year period available. Over this 10-year period the average number of dairy cattle increased from 16.3 to 20.6 million head in a nearly linear shape $\left(r^{2}=0.97\right)$ with a mean increment of 450.7 thousand head per year. At the same time, the beef cattle herd also increased linearly $\left(r^{2}=0.94\right)$ from 142 to 186 million head, but with a high rate of nearly 5.44 million heads per year. Those mean annual rates were used as the BAU scenario to estimate the size of cattle herd and associated $\mathrm{CH}_{4}$ emissions. Total herd size was estimated in 236.2; 266.1 and 295.5 million heads for the years 2010, 2015 and 2020, respectively. The associated emissions using the same methodology and factors as in the BINC were respectively 273.3; 307.3 and $341.3 \mathrm{Mt} \mathrm{CO}$-eq. Mitigation scenarios were built considering either a reduction in the cattle herd compared to the BAU option, or the adoption of mitigation strategies proposed by the IPCC (2007). A low mitigation scenario considered a $25 \%$ reduction of the annual in- 
creases, thus reaching 247.7 million head in 2020, and a high mitigation scenario assumed a 50\% reduction in the rates (thus reaching 227.4 million head in 2020). These scenarios are named thereafter Low- 25 and High- 50 . The High-50 scenario is not overly optimistic if deforestation of the Amazon is reduced as forecasted, because there is an evident synergy in slowing down deforestation rates and slowing down the annual increase of herd size.

In 2020, emissions from enteric fermentation of cattle would be respectively for the Low- 25 and High-50 scenarios 315.8 and 295.4 $\mathrm{Mt} \mathrm{CO}_{2}$-eq, i.e. a reduction in relation to BAU of 25.5 and $45.9 \mathrm{Mt} \mathrm{CO}$-eq. The cumulative emissions for the 2010-2020 period would be 3,380.5 Mt $\mathrm{CO}_{2}$-eq under the BAU baseline, and the amount of avoided emissions would be 187.1 $\mathrm{Mt} \mathrm{CO}_{2}$-eq (Low-25) and 336.9 $\mathrm{Mt} \mathrm{CO}_{2}$-eq (High-50). Default EX-ACT calculations were performed (Table 3) to recalculate emissions from enteric fermentation and manure management for different periods using the herd numbers under the BAU option and under the different mitigation scenarios.

Concerning the adoption of technical mitigation strategies, the three alternatives considered in EX-ACT (Bernoux et al., 2010) were compared (named respectively options A, B and C), i.e. improved feeding practices, use of specific agents or dietary additives, and longer term management changes and animal breeding. Two different dynamics of adoption by ranchers were considered: in dynamic-1c, adoption of the practices (in $\%$ of animal concerned) is linear between $0 \%$ in 2010 and $100 \%$ in 2020 , whereas for the dynamic- 2 scenario, the adoption is faster, reaching $100 \%$ in 2015 . The amount of GHG mitigated under all scenarios for the different dynamics are summarized in Table 4. Some measures might not be additive when applied simultaneously, such as the option A and option B, but this is probably not the case with option C. However, options were not combined in order to avoid overestimation of the reduction potential.

\section{Mitigation potential for Agriculture sector}

\section{No-tillage and cover-cropping}

The goal of the Brazilian Environment Ministry is to increase the area under no-tillage (NT) from 28 million ha to 40 million ha until 2020, which represents a conversion of 12 million ha from full tillage (FT) systems to conservationist systems. However, the annual rates of such an increase have not been specified, neither have the regions in which it will take place. Therefore, to estimate the potential of GHG mitigation from NT adoption in Brazil, the following assumptions were taken into account:

i) A linear increase in the adoption of NT systems from 2010 to 2020, which means an annual increase of 1.1 million ha;

ii) A mean rate of soil organic carbon (SOC) storage derived from the studies of Bernoux et al. (2006) and Bayer et al. (2006), which represent the rate in the top $20 \mathrm{~cm}$ of the soil profile for the South and Central (Cerrado) regions of Brazil; iii) The adoption of NT implies in changes in farming practices (Snyder et al., 2009) such

Table 3 - Total and average GHG emissions over different periods associated with enteric fermentation and manure management under the BAU, Low-25 and High-50 scenarios.

\begin{tabular}{|c|c|c|c|c|c|c|c|c|c|}
\hline \multirow{2}{*}{ Scenario } & \multicolumn{6}{|c|}{ Total over the period $\left(\mathrm{Mt} \mathrm{CO}_{2 \text { eq }}\right)$} & \multicolumn{3}{|c|}{ Yearly average $\left(\mathrm{Mt} \mathrm{CO}_{2 \text { eq }} \mathrm{yr}^{-1}\right)$} \\
\hline & $2010-2020$ & 2008-2012 & 2013-2017 & 2005 & 2010 & 2020 & $2010-2020$ & 2008-2012 & 2013-2017 \\
\hline \multicolumn{10}{|l|}{ BAU } \\
\hline $\begin{array}{l}\text { Enteric } \\
\text { fermentation }\end{array}$ & $3,482.6$ & $1,408.1$ & $1,583.0$ & 246.6 & 281.6 & 351.6 & 316.6 & 281.6 & 316.6 \\
\hline $\begin{array}{l}\text { Manure } \\
\text { Management }\end{array}$ & 673.3 & 272.5 & 306.0 & 47.8 & 54.5 & 67.9 & 61.2 & 54.5 & 61.2 \\
\hline \multicolumn{10}{|l|}{ Low Mitigation } \\
\hline $\begin{array}{l}\text { Enteric } \\
\text { fermentation }\end{array}$ & $3,290.2$ & $1,364.4$ & $1,495.6$ & 246.6 & 272.9 & 325.3 & 299.1 & 272.9 & 299.1 \\
\hline $\begin{array}{l}\text { Manure } \\
\text { Management }\end{array}$ & 636.4 & 264.2 & 289.3 & 47.8 & 52.8 & 62.9 & 57.9 & 52.8 & 57.9 \\
\hline Total & $3,926.7$ & $1,628.6$ & $1,784.8$ & 294.5 & 325.7 & 388.2 & 357.0 & 325.7 & 357.0 \\
\hline \multicolumn{10}{|l|}{ High Mitigation } \\
\hline $\begin{array}{l}\text { Enteric } \\
\text { fermentation }\end{array}$ & $3,097.9$ & $1,320.7$ & $1,408.1$ & 246.6 & 264.1 & 299.1 & 281.6 & 264.1 & 281.6 \\
\hline $\begin{array}{l}\text { Manure } \\
\text { Management }\end{array}$ & 599.6 & 255.8 & 272.5 & 47.8 & 51.2 & 57.9 & 54.5 & 51.2 & 54.5 \\
\hline Total & $3,697.5$ & $1,576.5$ & $1,680.7$ & 294.5 & 315.3 & 357.0 & 336.1 & 315.3 & 336.1 \\
\hline
\end{tabular}

Sci. Agric. (Piracicaba, Braz.), v.67, n.1, p.102-116, January/February 2010 
Table 4 - Technical reduction potential for enteric methane emissions due to improved feeding practices (option 1), specific agents and dietary additives (option 2) and longer term management change and animal breeding (option 3); considering herd sizes under the BAU (Business as Usual), Low-25 (25\% reduction of the annual increase, thus reaching 247.7 million head in 2020), High-50 (50\% reduction in the rates, thus reaching 227.4 million head in 2020) scenarios and with two dynamic for adoption of the practices.

\begin{tabular}{|c|c|c|c|c|c|c|c|c|}
\hline \multirow{2}{*}{ Scenario } & \multicolumn{5}{|c|}{ Total over the period $\left(\mathrm{Mt} \mathrm{CO}_{2-\mathrm{eq}}\right)$} & \multicolumn{3}{|c|}{ Yearly average $\left(\mathrm{Mt} \mathrm{CO}_{2 \text { eq }} \mathrm{yr}^{-1}\right)$} \\
\hline & $2010-2020$ & $2008-2012$ & 2013-2017 & 2010 & 2020 & $2010-2020$ & $2008-2012$ & 2013-2017 \\
\hline \multicolumn{9}{|l|}{$\mathrm{BAU}$} \\
\hline \multicolumn{9}{|l|}{ Dynamic 1} \\
\hline Option A & 60.2 & 2.9 & 26.5 & 0 & 11.6 & 5.5 & 0.6 & 5.3 \\
\hline Option B & 38.3 & 1.9 & 16.8 & 0 & 7.4 & 3.5 & 0.4 & 3.4 \\
\hline Option C & 52.7 & 2.5 & 23.1 & 0 & 10.2 & 4.8 & 0.5 & 4.6 \\
\hline \multicolumn{9}{|l|}{ Dynamic 2} \\
\hline Option A & 86.5 & 5.8 & 46.4 & 0 & 11.6 & 7.9 & 1.2 & 9.3 \\
\hline Option B & 54.9 & 3.7 & 29.5 & 0 & 7.4 & 5.0 & 0.7 & 5.9 \\
\hline Option C & 75.6 & 5.1 & 40.5 & 0 & 10.2 & 6.9 & 1.0 & 8.1 \\
\hline \multicolumn{9}{|l|}{ Low-25 } \\
\hline \multicolumn{9}{|l|}{ Dynamic 1} \\
\hline Option A & 56.5 & 2.8 & 25.0 & 0 & 10.8 & 5.1 & 0.6 & 5.0 \\
\hline Option B & 35.9 & 1.8 & 15.9 & 0 & 6.8 & 3.3 & 0.4 & 3.2 \\
\hline Option C & 49.3 & 2.4 & 21.8 & 0 & 9.4 & 4.5 & 0.5 & 4.4 \\
\hline \multicolumn{9}{|l|}{ Dynamic 2} \\
\hline Option A & 81.3 & 5.6 & 43.8 & 0 & 10.8 & 7.4 & 1.1 & 8.8 \\
\hline Option B & 51.6 & 3.6 & 27.8 & 0 & 6.8 & 4.7 & 0.7 & 5.6 \\
\hline Option C & 70.9 & 4.9 & 38.2 & 0 & 9.4 & 6.4 & 1.0 & 7.6 \\
\hline \multicolumn{9}{|l|}{ High-50 } \\
\hline \multicolumn{9}{|l|}{ Dynamic 1} \\
\hline Option A & 52.7 & 2.7 & 23.5 & 0 & 9.9 & 4.8 & 0.5 & 4.7 \\
\hline Option B & 33.4 & 1.7 & 14.9 & 0 & 6.3 & 3.0 & 0.3 & 3.0 \\
\hline Option C & 45.9 & 2.3 & 20.5 & 0 & 8.7 & 4.2 & 0.5 & 4.1 \\
\hline \multicolumn{9}{|l|}{ Dynamic 2} \\
\hline Option A & 76.1 & 5.4 & 41.3 & 0 & 9.9 & 6.9 & 1.1 & 8.3 \\
\hline Option B & 48.3 & 3.4 & 26.2 & 0 & 6.3 & 4.4 & 0.7 & 5.2 \\
\hline Option C & 66.3 & 4.7 & 35.9 & 0 & 8.7 & 6.0 & 0.9 & 7.2 \\
\hline
\end{tabular}

*2008-2012 and 2013-2017 correspond respectively to the $1^{\text {st }}$ and $2^{\text {nd }}$ commitment periods under the Kyoto Protocol (even though Brazil is not subject to Quantified Emission Reductions, it is a useful comparison parameter).

as the use of machinery, lime, $\mathrm{N}$ fertilizer, and can also modify the fluxes of the other GHG such as $\mathrm{N}_{2} \mathrm{O}$ and $\mathrm{CH}_{4}$ from soils when compared with FT systems. Therefore, for the fluxes of $\mathrm{N}_{2} \mathrm{O}$ and $\mathrm{CH}_{4}$ from soils we used the average of results obtained by Siqueira Neto (2006), Gomes (2006) and Carvalho et al. (2009); for the changes related to the use of machinery (i.e. agricultural operations) the values presented by Gomes (2006) were used, and for the emissions related to lime and $\mathrm{N}$ fertilizer we assumed there is no difference between the NT and FT.

Considering the assumptions described above, the amount in $\mathrm{CO}_{2}$-eq that can be sequestered by the adoption of NT until 2020 was estimated. In addition to this initial scenario (named here as "Committed Mitiga- tion"), two other scenarios were considered: one with half of the increase in the area under NT (Low Mitigation), which means that in 2020 only 34 million ha would be under NT; and a second scenario considering doubling the increase, i.e., 52 million ha under NT in the year of 2020.

Table 5 shows the rates of GHG emissions or removals associated with the soil as well as with the use of machinery in agricultural practices in both tillage systems (i.e. NT and FT), and presents the net $\mathrm{CO}_{2}$ uptake rate resulting from the conversion of FT to NT systems in Brazil. The adoption of NT system results in a $\mathrm{N}_{2} \mathrm{O}$ emission rate $51 \%$ higher than in the FT system (Table 5). Likewise, $\mathrm{CH}_{4}$ is $8.5 \%$ less absorbed in NT than in the FT 
system. Otherwise, the GHG emissions (expressed as $\mathrm{CO}_{2}$-eq.) from agricultural operations (machinery) in NT system areas are only $34 \%$ of the emissions in FT systems. Moreover, the SOC is a sink of atmospheric $\mathrm{CO}_{2}$ at a rate of $1.98 \mathrm{Mg} \mathrm{CO}$-eq ha ${ }^{-1} \mathrm{yr}^{-1}$. Consequently, the conversion from FT to NT systems represents in Brazil a net $\mathrm{CO}_{2}$ uptake rate of $1.91 \mathrm{Mg} \mathrm{CO}_{2}$-eq $\mathrm{ha}^{-1} \mathrm{yr}^{-1}$.

The conversion of 12 million ha into the NT system until 2020 (Committed mitigation scenario) may represent a removal of $138.5 \mathrm{Mt} \mathrm{CO}$-eq. from the atmosphere (Table 6). The other two scenarios can be used to illustrate the mitigation potential and emphasize the importance of implementing or not the committed mitigation scenario. For example, if the adoption of NT is encouraged and 24 instead 12 million ha are converted to NT until 2020, the gain can be doubled, which means 277.1 $\mathrm{Mt} \mathrm{CO}$-eq. However, if only $50 \%$ of the initial goal is reached, the $\mathrm{CO}_{2}$ uptake will be about $69 \mathrm{Mt} \mathrm{CO}_{2}$-eq. (Table 2). Yet, it is important to highlight that SOC storage rate, which is the main contributor to the mitigation potential of no tillage system (Table 6) represents only the $\mathrm{C}$ storage in the top $20 \mathrm{~cm}$ soil profile. Thus, it can be suggested that the SOC gain could be greater if the whole soil profile was evaluated.

NT system presents several benefits when compared with FT systems. However, soil C accumulation in NT systems can be higher when associated with integrated management systems, such as the implementation of integrated crop-livestock systems under no tillage (ICLNT). ICLNT includes the diversification of activities by strategic integration of pastures and agriculture in order to benefit both. Associating the increased levels of soil fertility in the crop areas under NT system, with the enhanced capacity of well-managed pastures of storing C into the soil, it is expected that results would generate not only a large increase in soil $\mathrm{C}$ stocks but also a reduction of $\mathrm{CO}_{2}$ emissions to the atmosphere (Carvalho et al., 2010). Salton (2005) and Carvalho et al. (2010) evaluated the capacity of ICLNT systems in increasing soil $\mathrm{C}$ stocks and verified that the association of pastures with crops under NT can result in rates of soil $\mathrm{C}$ accumulation two to four times larger than those observed in the conversion of FT to NT and systems. In addition to the mentioned increase in soil $\mathrm{C}$ stocks, the ICLNT system results in improved land use efficiency, demanding less land for agricultural expansion, and consequently, reducing deforestation rates.

\section{Flooded rice}

Rice has an important role in methane emissions, caused by organic matter decomposition in anaerobic conditions (IPCC, 2006). In Brazil, emissions from rice production amounted to $5.4 \mathrm{Mt} \mathrm{CO}_{2}$-eq, $1.2 \%$ of the total emissions of $467 \mathrm{Mt} \mathrm{CO}$-eq from Agriculture sector in 2005 (Cerri et al., 2009). Irrigated rice represented 33\% of all productions in 1994, out of which $92.2 \%$ were permanently flooded, $7.5 \%$ were cropped in naturally flooded areas and $0.3 \%$ were managed under intermittent irrigation systems (Brasil, 2006). Historically, rice production has increased mainly due to improved technology. From 1997 to 2007, there was an increase of 2.7 $\mathrm{Mt}$ in domestic production with a small reduction in the area under production. The projection for 2010 is that $12 \mathrm{Mt}$ will be produced in $2.9 \mathrm{Mha}$, reaching $13.4 \mathrm{Mt}$ in 2020 (CONAB, 2009; Brasil, 2008b).

Although rice field methane emissions in Brazil are relatively small, the adoption of different water management systems can result in even lower emissions. Sass

Table 5 - Net $\mathrm{CO}_{2}$-eq uptake rate due to the conversion of full tillage to no tillage, and soil organic carbon (SOC), $\mathrm{N}_{2} \mathrm{O}$, $\mathrm{CH}_{4}$, and machinery rates of emission or removal comparing the tillage systems in Brazil.

\begin{tabular}{lccccc}
\hline & $\mathrm{SOC}$ & $\mathrm{N}_{2} \mathrm{O}$ & $\mathrm{CH}_{4}$ & Machinery & Net $\mathrm{CO}_{2 \text { eq }}$ uptake rate \\
\hline & -1.982 & 0.477 & -0.035 & 0.048 & \\
No tillage & - & 0.315 & -0.038 & 0.141 & \\
Full tillage & -1.98 & 0.162 & 0.002 & -0.093 &
\end{tabular}

$-1.91$

${ }^{1}$ Machinery in NT systems means sowing + harvest, while that in FT systems means sowing + plowing +2 harrowing + harvest (Gomes, 2006; Zanatta, 2005). ${ }^{2}$ Negative values means uptake of $\mathrm{CO}_{2}$-eq., while that positive values means emission of $\mathrm{CO}_{2}$-eq.

Table 6 - Net $\mathrm{CO}_{2}$-eq uptake due to the conversion of full tillage to no tillage and the emission or removal associated with soil organic carbon (SOC), $\mathrm{N}_{2} \mathrm{O}$ and $\mathrm{CH}_{4}$ from soils and machinery use in no tillage systems in Brazil.

\begin{tabular}{lccccc}
\hline Scenario & $\mathrm{SOC}$ & $\mathrm{N}_{2} \mathrm{O}$ & $\mathrm{CH}_{4}$ & Machinery & Net $\mathrm{CO}_{2 \text { eq }}$ uptake rate \\
\hline & -71.92 & 5.9 & 0.1 & -3.4 & -69.3 \\
Low Mitigation & -143.7 & 11.8 & 0.2 & -6.8 & -138.5 \\
Committed Mitigation & -287.5 & 23.6 & 0.4 & -13.5 & -277.1 \\
\hline High Mitigation & - &
\end{tabular}

${ }^{1}$ Machinery in NT systems means sowing + harvest, while that in FT systems means sowing + plowing +2 harrowing + harvest (Gomes, 2006; Zanatta, 2005). ${ }^{2}$ Negative values means uptake of $\mathrm{CO}_{2}$-eq., while that positive values means emission of $\mathrm{CO}_{2}$-eq. 
et al. (1992) and Yagi et al. (1996) reported that regular drainage may represent the most efficient method to minimize emissions. The authors found that a single drainage during the rice growth phase reduced methane emissions by $50 \%$. In addition, multiple drains (two to three days) every three weeks throughout the growing season reduced emissions to negligible values. Considering that the area under irrigated rice will remain constant until 2020 and that permanently flooded areas would revert to periodically drained systems (Sass et al., 1992; Yagi et al., 1996), emissions could be reduced from the $5.4 \mathrm{Mt} \mathrm{CO}_{2}$-eq (BAU scenario) reported by Cerri et al. (2009) to $2.9 \mathrm{Mt} \mathrm{CO}$-eq annually, totaling the emission reduction of $25 \mathrm{Mt} \mathrm{CO}_{2}$-eq for the 2010-2020 period.

\section{Sugarcane management}

The sugarcane production area in Brazil reached 7.4 Mha during the 2008/2009 crop year, producing $570 \mathrm{Mt}$ of feedstock for $31 \mathrm{Mt}$ of sugar and $27.5 \mathrm{Mm}^{3}$ of ethanol (CONAB, 2009). The Central-South region responds for $86 \%$ in cropped area, and the state of Sao Paulo has the largest production area with 4.2 Mha which accounted for $58 \%$ of total production in 2008/2009 (UNICA, 2009). The area cropped with sugarcane expanded by 2 Mha in the last five years (CONAB, 2009). This is related to the increased consumption of ethanol used in flex-fuel vehicles, which accounted for $90 \%$ of all new vehicle sales in 2008 (UNICA, 2009).

Two projections of growth were considered to estimate the need for new areas of sugarcane in order to supply the bioethanol and sugar demand for 2020. The National Energy Plan - 2030 (NEP) estimates that there will be an increase of 3.9 Mha by 2020, when annual ethanol production will reach $52 \mathrm{Mm}^{3}$ (Table 7) (Brasil, 2007). NPCC indicates that it will be necessary to produce 73 $\mathrm{Mm}^{3}$ ( $1^{\text {st }}$ and $2^{\text {nd }}$ generation) to supply the Brazilian market in 2020 (Brasil, 2008a). Maintaining a proportion of $55 \%$ and $45 \%$ of the sugarcane area for bioethanol and sugar respectively (CONAB, 2009), the area needed to supply that amount will be $18.4 \mathrm{Mha}$, considering a sugarcane yield of $80.1 \mathrm{Mg} \mathrm{ha}^{-1}$ and an ethanol yield of 90 litters per ton of biomass (Table 7).

Burning leaves and tops in order to facilitate sugarcane harvest has been a common practice in Brazil. However, due to environmental and economic reasons, manu- ally harvested, burned sugarcane has been progressively replaced by mechanically harvested cane with maintenance of the crop residues on the field. There exists a positive correlation between the maintenance of sugarcane trash and the increase in soil organic carbon (SOC) content, influenced by time since adoption of the unburned harvest, soil texture and soil disturbance (Cerri et al., 2004; Galdos et al., 2009).

Cerri et al. (2009) reviewed published comparisons of soil carbon stocks between burned and unburned areas. The average annual increase in soil carbon stocks down to $30 \mathrm{~cm}$ was $1.5 \mathrm{Mg} \mathrm{C} \mathrm{ha}{ }^{-1}$. Assuming that the sugarcane area harvested mechanically without burning will represent $50 \%$ in $2010,100 \%$ in 2020 and that the increase will be linear, we estimated the potential for carbon sequestration in this period. Since soil $\mathrm{C}$ sequestration occurs in the agricultural phase of production, regardless of the final processed product (sugar or ethanol), thus the total sugarcane areas were considered in the calculation. Considering the 2010-2020 period, the conservation management of sugarcane residues has the potential to sequester $404 \mathrm{Mt} \mathrm{CO}_{2}$-eq under the NEP scenario, and $619 \mathrm{Mt} \mathrm{CO}_{2}$-eq under the NPCC scenario in the form of soil carbon in the first $30 \mathrm{~cm}$. Cerri et al (2004) estimated that the burning release about $370 \mathrm{~kg}$ Ceq $\mathrm{ha}^{-1} \mathrm{yr}^{-1}$; therefore, under the NEP and NPCC scenarios for the period 2010-2020, the emissions of GHG is equivalent to $29.3 \mathrm{Mt} \mathrm{CO}_{2}$-eq (NEP) and $29.9 \mathrm{Mt} \mathrm{CO}_{2}^{-}$ eq (NPCC). Discounting those emissions the net benefice is respectively $375 \mathrm{Mt} \mathrm{CO}_{2}$-eq and $579 \mathrm{Mt} \mathrm{CO}_{2}$-eq.

\section{Mitigation potential from bio-energy}

\section{Bioethanol}

Sugarcane-derived bioethanol production has increased in Brazil since the implementation of the 'PRO ÁLCOOL' biofuel program in the 70's (Coelho, 2000). The program went through a stagnation period between 1990 to 1999 but was reactivated soon thereafter. From its beginning until 2000, $227 \mathrm{Mm}^{3}$ of bioethanol (anhydrous and hydrated) were produced, avoiding the emission of $630 \mathrm{Mt} \mathrm{CO}_{2}$-eq to the atmosphere (Cerri et al, 2009). Between 2000 and 2005, the production of first generation bioethanol increased at a rate of $9.7 \%$ per year, and current projections indicate the annual growth rate will reach $8.7 \%$ between 2006 and 2010 .

Table 7 - Sugarcane production aspects expected for 2010 and 2020 considering the National Energy Plan - 2030 (NEP) and the National Plan on Climate Change (NPCC) scenarios.

\begin{tabular}{lrrrr}
\hline & \multicolumn{2}{c}{2010} & \multicolumn{2}{c}{2020} \\
\cline { 2 - 5 } Production aspects & & \multicolumn{2}{c}{ Scenarios } & NPCC \\
\cline { 2 - 5 } & NEP & NPCC & $1,002.0$ & $1,474.7 *$ \\
\hline Biomass $\left(10^{6} \mathrm{Mg}\right)$ & 518.4 & $700.3 *$ & 52.0 & $92.9 *$ \\
Sugar $\left(10^{6} \mathrm{Mg}\right)$ & 36.0 & $44.1 *$ & 51.5 & 72.9 \\
Bioethanol $\left(10^{6} \mathrm{~m}^{3}\right)$ & 25.5 & 31.7 & 10.6 & $18.4 *$ \\
Area $\left(10^{6} \mathrm{ha}\right)$ & 6.7 & $7.4 * *$ & & NEP \\
\hline
\end{tabular}

"Estimate value considering production aspects on NEP (National Energy Plan - 2030) scenario to reach NPCC (National Plan on Climate Change) bioethanol projections. ${ }^{* *}$ CONAB numbers. 
Data from the last five years (2005-2009) indicate that Brazil consumed about $100 \mathrm{Mm}^{3}$ of bioethanol, between 2005 and 2009 (UNICA, 2009). For the next decade, there is a trend for increased bioethanol consumption and exports according to both the NEP (Brasil, 2007) and the NPCC (Brasil, 2008a) - Figure 3. To achieve both scenarios, two important factors must occur: (i) the development of technologies for $2^{\text {nd }}$ generation bioethanol production and (ii) an expansion in sugarcane production areas (Brasil, 2007).

The $2^{\text {nd }}$ generation bioethanol production will account for $20 \mathrm{Mm}^{3}$ until 2020, increasing the current pro-

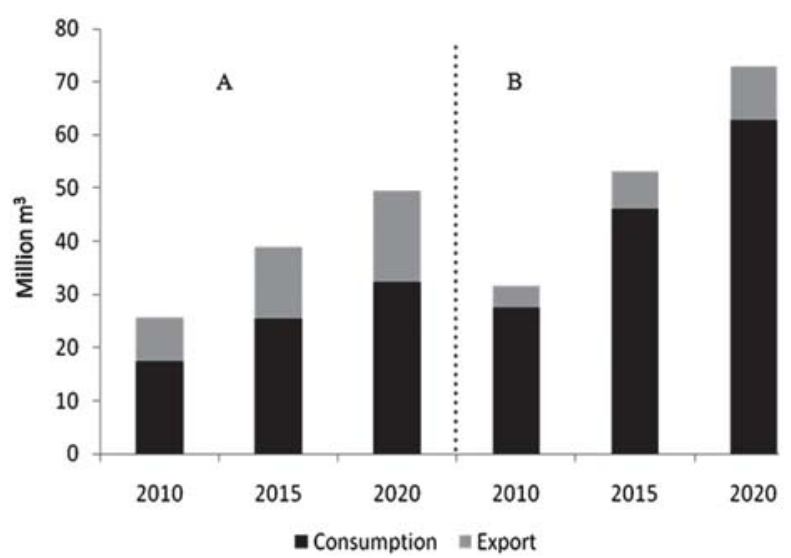

Figure 3 - Estimates of Brazilian domestic consumption and export of ethanol in 2010, 2015 and 2020. Adapted from Brasil (2007) (A); Brasil (2008a) (B). ductivity from $0.13 \mathrm{Mm}^{3} \mathrm{yr}^{-1}$ to $4.53 \mathrm{Mm}^{3} \mathrm{yr}^{-1}$ in the NEP scenario. To reach this amount, an increase from 600 to $17,000 \mathrm{Mg}$ of biomass will be needed, which represents a change from $0.6 \%$ to $7.3 \%$ of total biomass production in 2020 (Brasil, 2007).

The sugarcane expansion will occur differently on both scenarios as shown at Table 8. The NEP scenario implies an increase of $3.9 \mathrm{Mha}$ to reach the $52 \mathrm{Mm}^{3}$ of bioethanol, while an additional area of 11 Mha would be needed to produce $73 \mathrm{Mm}^{3}$ from $1^{\text {st }}$ and $2^{\text {nd }}$ generation biofuel in the NPCC scenario (Table 8). Expansion will consider the 'Sugarcane Agroecological Zoning', in which areas protected by Brazilian environmental law such as the Amazon and Pantanal biomes will not be used (EMBRAPA, 2009). For offset estimates, both scenarios were considered. According to NEP, Brazil will consume around $230 \mathrm{Mm}^{3}$ of $1^{\text {st }}$ generation bioethanol and $20 \mathrm{Mm}^{3}$ of $2^{\text {nd }}$ generation cellulosic bioethanol for energy proposes over the next decade (Brasil, 2007). Considering that $1 \mathrm{~m}^{3}$ of anhydrous bioethanol will avoid $2.11 \mathrm{Mg} \mathrm{CO}_{2}$-eq m${ }^{-3}$ on 2020 (Macedo et al., 2008), Brazil will offset $527.5 \mathrm{Mt} \mathrm{CO}_{2}$-eq replacing fossil fuel to sugarcane bioethanol in the next decade on NEP scenario. In the NPCC scenario, bioethanol consumption will increase significantly until 2020 , reaching $63 \mathrm{Mm}^{3}$. For the 2010-2020 projection, $501 \mathrm{Mm}^{3}$ bioethanol $\left(1^{\text {st }}\right.$ and $2^{\text {nd }}$ generation) will be necessary to supply domestic demand. Considering the same factors applied to the NEP scenario, Brazil will offset 1,057 $\mathrm{Mt} \mathrm{CO}_{2}$-eq in the NPCC

Table 8 - Estimates of the expansion area planted with the main oilseeds for biodiesel production in Brazil.

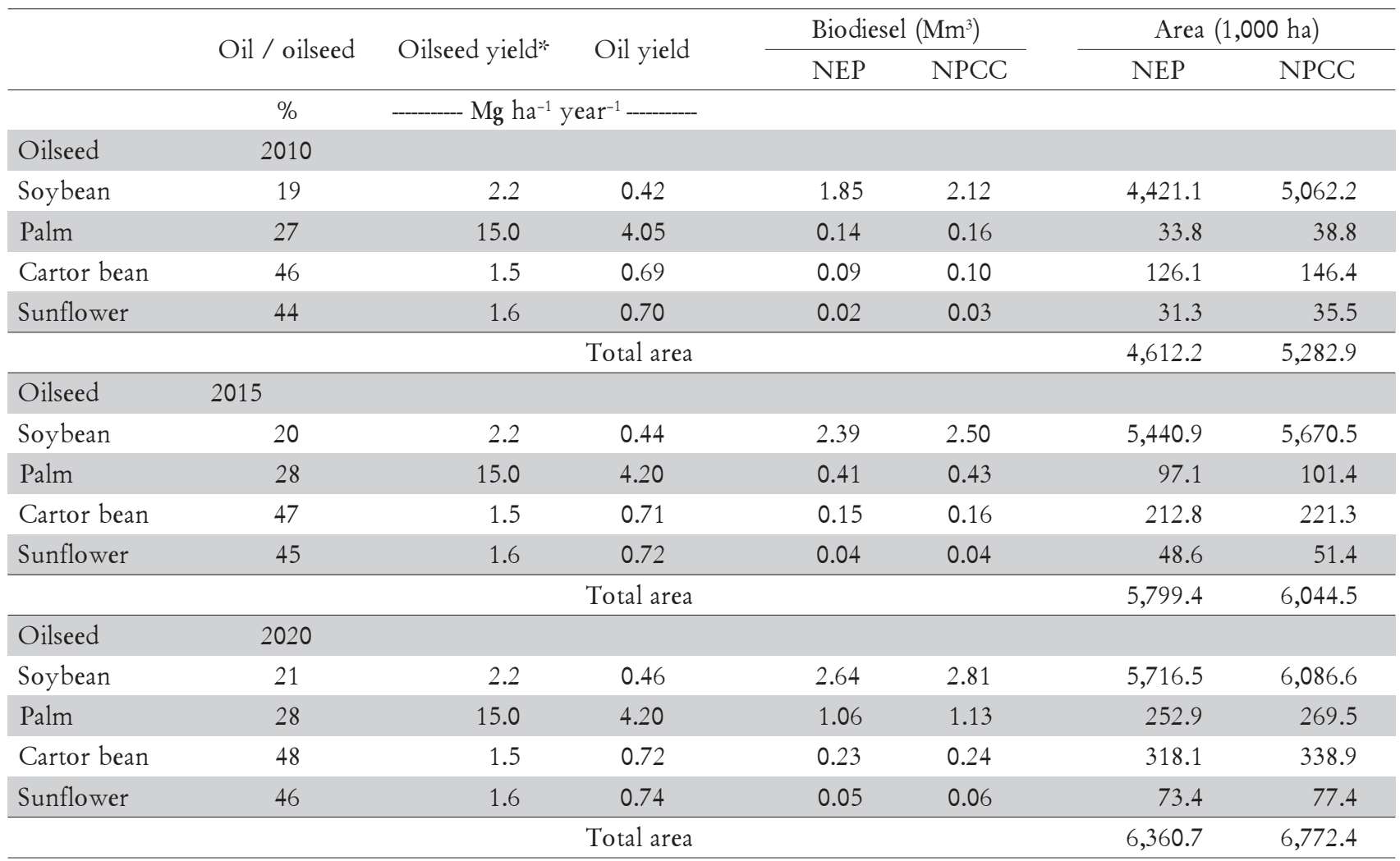

Source: IBGE, 2008. NEP: National Energy Plan - 2030. NPCC: National Plan on Climate Change. 
scenario. Besides future projections, $232 \mathrm{Mt} \mathrm{CO}_{2}$-eq were already avoided in the 2005-2009 period, considering bioethanol for transport, surplus electricity and surplus bagasses. This is a significant amount, considering that all avoided emissions from 1975 to 2000 added up to 630 Mt $\mathrm{CO}_{2}$-eq (Cerri et al., 2009).

In addition to the important role of fossil fuel substitution, other components of bioethanol production help mitigate GHG emissions. Bagasse, a fibrous residue remaining from sugarcane crushing, is used to generate electric power and steam for processing ethanol. Ethanol plants, through improvements in boiler efficiency, have increasingly exported bagasse-derived surplus electricity. This happens especially in periods of the year when hydroelectric dams are at low levels, thus substituting other energy sources such as thermal plants. Therefore, co-generation represents an increasingly significant role in avoiding GHG emissions from power generation. When current and predicted surplus electricity potentials are considered (Macedo and Seabra, 2008), $153 \mathrm{Mt} \mathrm{CO}$-eq (NEP scenario) and $283 \mathrm{Mt} \mathrm{CO}_{2}$-eq (NPCC scenario) could be avoided through cogeneration.

\section{Biodiesel}

The Brazilian federal government has created the National Biodiesel Production and Use Program (PNPB) aiming at the implementation of sustainable production and use of biodiesel. Focusing on this issue, a federal law was passed in 2005 in order to establish the addition of $2 \%$ and $5 \%$ biodiesel to the diesel oil in 2008 and 2013, respectively. Thus, a preliminary estimate showed that there was a need to produce $0.80 \mathrm{Mm}^{3}$ of biodiesel in 2008 and $2 \mathrm{Mm}^{3}$ in 2013 to supply the demand established (Brasil, 2004). Three years after the first estimate, data published in NPCC reported that, considering the addition of $2 \%, 3 \%$ and $5 \%$ biodiesel to fossil diesel, the projected demand was 1.08 and $2.81 \mathrm{Mm}^{3}$ in 2008 and 2013, respectively (Brasil, 2008a).

Figure 4 represents an estimate of the requirement for biodiesel production to supply domestic demand by 2020. Estimates for this sector were not so different because the calculations are performed based on projections of the federal government. According to demand

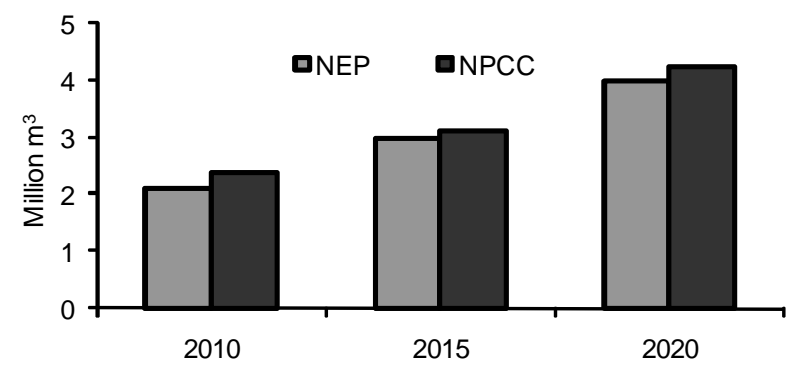

Figure 4 - Estimated annual biodiesel production in Brazil in 2010, 2015 and 2020 considering the National Energy Plan - 2030 (NEP) and the National Plan on Climate Change (NPCC). Adapted from Brasil (2007); Brasil (2008a). studies prepared by the NEP in Brazil, annual production of biodiesel until 2020 was estimated at $3.90 \mathrm{Mm}^{3}$ (first scenario), whereas the percentage of blending with diesel in 2010 will be 5\%, while in 2015 and 2020 it will be $6 \%$ (Brasil, 2007). Data of NPCC were slightly higher (second scenario), in which annual production until 2020 was estimated at $4.25 \mathrm{Mm}^{3}$ (Brasil, 2008a). Brazil is seen as a future leader in biodiesel production due to its excellent climate and soil conditions, and vast territorial extension appropriate for a variety of oil crops. Within this context, some oilseeds like soybean, palm, castor bean and sunflower have received greater focus by the National Program for Production and Use of Biodiesel (PNPB, 2004).

Besides oil crops, a promising biodiesel feedstock is beef tallow. Tallow is a greasy residue consisting of triglycerides, mainly palmitic (30\%), stearic (20-25\%) and oleic acid (45\%) (Graboski and McCormick, 1998). Each animal slaughtered provides an average of $15 \mathrm{~kg}$ of tallow (RBB, 2006). Assuming a yield of $80 \%$ in processing tallow to biodiesel and the herd numbers estimated the potential for tallow-derived biodiesel production in the 2010-2020 period was calculated as $9.69 \mathrm{Mm}^{3}$.

The estimate in NEP and NPCC scenarios (Figure 5 ) showed the estimation for biodiesel production from five raw materials: beef tallow (27\%), soybean $(58 \%)$, palm $(10 \%)$, castor bean $(4 \%)$ and sunflower $(1 \%)$. This calculation considered the production of each oilseed in the Brazilian territory (Brasil, 2007) and the amount of animals slaughtered until 2020 in Brazil. We assumed a decrease in the use of soybean as feedstock in the long term, and an increase in the participation of other crops, especially palm. The total of biodiesel production in the 2010-2020 period was calculated as $33.33 \mathrm{Mm}^{3}$ in NEP scenario and $35.23 \mathrm{Mm}^{3}$ in NPCC scenario. The baseline was estimated by considering the differences in combustion efficiency between biodiesel and petroleum diesel. Calculation using calorific values and densities of biodiesel and petroleum diesel showed that the energy content of $1 \mathrm{~m}^{3}$ biodiesel is equal to that of $0.889 \mathrm{~m}^{3}(0.78$ $\mathrm{Mg}$ ) petroleum diesel. The quantity of biodiesel from tallow and oil crops would replace $31.31 \mathrm{Mm}^{3}$ of fossil diesel. Considering that $1 \mathrm{~m}^{3}$ of biodiesel will avoid 3.14

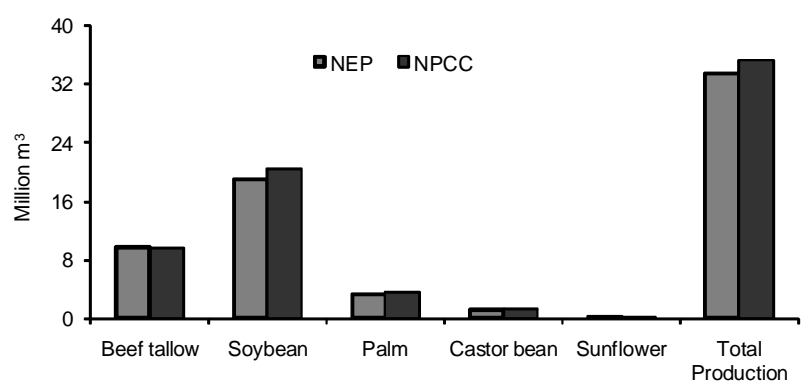

Figure 5 - Estimated biodiesel production in the National Energy Plan - 2030 (NEP) and in the National Plan on Climate Change (NPCC) scenarios considering the main feedstocks in Brazil. 
$\mathrm{Mg} \mathrm{CO}_{2}$-eq $\mathrm{m}^{-3}$, Brazil will offset ranging from 93 up to $98 \mathrm{Mt} \mathrm{CO}$-eq replacing fossil diesel to biodiesel in the next decade.

According to the National Energy Plan (Brasil, 2007), Brazil will need to expand the area planted with oilseeds to meet its domestic demand for biodiesel production. Livestock intensification in currently underutilized pastureland could allow the expansion of grains and oil seeds. Table 8 presents an estimate of the expansion area needed to meet the demand for biodiesel production until 2020, considering the capacity of oilseed production (IBGE, 2008). In accordance with earlier projections, the requirements for expansion areas in the NEP and NPCC scenarios will be 6.4 and 6.8 Mha, respectively.

\section{Total mitigation potential for Brazil}

On November $13^{\text {th }} 2009$, Brazilian authorities announced that the country will target a reduction in its greenhouse gas emissions of between 36.1 and $38.9 \%$ from projected levels in 2020; this will be done on a voluntary basis, and that Brazil will not accept mandatory cuts. Brazilian Environment Minister said that the majority of Brazil's emission cuts will come from slowing deforestation (20.9\% coming from the reduction in the Amazon and $3.9 \%$ of the Cerrado), then followed by a cut in the energy sector (from $6.1 \%$ to $7.7 \%$ ), agriculture (from $4.9 \%$ to $6.1 \%$ ) and steel $(0.3 \%$ to $0.4 \%)$. Total cuts would be between $36.1 \%$ and $38.9 \%$, assuming a GDP growth between $4 \%$ and $6 \%$. However, Brazilian authorities did not precise the level of GHG emissions expected for the year 2020 under a BAU option for all sectors, and real emissions reductions will depend on the baseline adopted and on the assumptions used to project the future emissions' trajectory. Assuming that Brazilian authorities also used the BAU-NPCC baseline for deforestation (the average rates from 1996 to 2005, i.e. $19,533 \mathrm{~km}^{2} \mathrm{yr}^{-1}$ for the Amazon region and that they considered the Mitigation-Committed scenario, i.e. a reduction of $80 \%$ in 2020 in relation to the BAU-NPCC, the avoided emission from Amazon deforestation would be around $510 \mathrm{Mt} \mathrm{CO}$ eq. This estimate is coherent with the value announced by the Government: a total mitigation ranging from 975 to $1062 \mathrm{Mt} \mathrm{CO}$-eq in 2020 with 20.9\% coming from the reduction in the Amazon. Using Government numbers, the Amazonian deforestation reduction is $669 \mathrm{MtCO}_{2}$-eq. The reduction target to be met by other sectors is in the range of $306-383 \mathrm{MtCO}_{2}^{-}$ eq. The potential reduction in agriculture (4.9 to $6.1 \%$ ) proposed by the Government corresponds to a mitigation ranging from 133-166 $\mathrm{MtCO}_{2}$-eq.

We calculated (Table 9) that the potential of reduction in the agriculture sector may vary from 178.3 to 445 $\mathrm{Mt} \mathrm{CO}$-eq in the year of 2020 in relation to a BAU hypothesis. Therefore, our estimates for agriculture and livestock are larger than Government figures, and this difference is because in our understanding, biofuels are directly related to the agriculture rather than the energy sector. Our results represent a reduction of 8.8 to 22.0 $\%$ in relation to the total national GHG emissions calculated for 2005 by Cerri et al. (2009).

Two types of mitigation actions can be considered: i) increasing $\mathrm{C}$ sinks, and ii) reducing emissions. Increasing $\mathrm{C}$ sinks represents 19 to $39 \%$ of the mitigation potential, and reducing emissions, 81 to $61 \%$. A large part that corresponds to $106-195 \mathrm{Mt} \mathrm{CO} 2$-eq of total potential from emission reductions is due to fossil fuel offset from ethanol and biodiesel. These numbers emphasize that bioenergy represents a major opportunity for Brazil and would contribute to global warming mitigation.

The potential of sinks is high, but perhaps more difficult to verify, and associated with a large number of agents. Nevertheless, the probability of successful implementation is high, mostly due to co-benefits embedded in those systems, as for instance the erosion control effect of NT systems. In practice, most of those mitigation actions are linked. Slowing down deforestation will decrease new land availability, thus driving the conversion from underutilized pastures to cropland or managed

Table 9 - Range of mitigation potential in $\mathrm{MtCO}_{2}$-eq for the 2010-2020 period and for the year 2020.

\begin{tabular}{lcc}
\hline Activity or sector & $2010-2020$ period & 2020 \\
\hline & & \\
Cattle livestock enteric fermentation and manure: & $229.2-458.4$ & $31.3-62.5$ \\
$\quad$ Herd size effect & $33.4-86.5$ & $6.3-11.6$ \\
$\quad$ Additional technical mitigation & $52.4-1,000$ & $5.2-100$ \\
Afforestation/reforestation & $69.3-277.1$ & $11.5-46.2$ \\
No-tillage expansion & 25 & 2.5 \\
Rice & $375-579$ & $15.9-27.6$ \\
Sugarcane: Conversion of burned to unburned harvest (C Sequestration) & & \\
Bioenergy & $527.5-1,057$ & $68.5-132.6$ \\
$\quad$ Ethanol from sugarcane (offset) & $153-283$ & $26.0-50.5$ \\
$\quad$ Cogeneration from bagasse & $93-98$ & $11.1-11.9$ \\
$\quad$ Biodiesel & $1,557.8-3,864$ & $178.3-445.4$ \\
Full range & & \\
\hline
\end{tabular}

Sci. Agric. (Piracicaba, Braz.), v.67, n.1, p.102-116, January/February 2010 
forests. Those patterns will certainly change from state to state according to the dominant practices, but also to commitments taken at the state level. For instance, the state of São Paulo has recently written into law a reduction of $20 \%$ of 2005 GHG emissions, by 2020 . As deforestation is not a significant issue in São Paulo, the effort will have to be focused almost exclusively on the remaining sectors: Energy, Industries, Waste and Agriculture. According to the State governor, the first estimates of the effort correspond to a reduction from $122 \mathrm{Mt} \mathrm{CO}_{2}-$ eq (in 2005) to $98 \mathrm{Mt} \mathrm{CO}_{2}$-eq. Agriculture will certainly have an important role in helping reduce emissions. As calculated above for Brazil, the mitigation potential of the agricultural sector and managed forests represent a maximum of $22 \%$ at the national scale, showing that such a commitment is not an easy target. Fortunately, São Paulo state has an important share of the mitigation potential, mainly concerning sugarcane cropping (and thus bioenergy) and managed forests. This last sector would certainly merit an even more ambitious goal for 2020 .

\section{Recommendations for policy makers and future re- search needs}

Brazil needs to maintain and even increase actions for GHG emission reduction from deforestation. In this aspect, the Federal Government has announced ambitious targets to reach this goal. More efforts need to be implemented in already cleared areas, mainly in the livestock sector. There is a need to not only increase productivity, but at the same time decrease GHG emissions associated to that activity. In doing so, a more efficient use of pastures could free more land to produce food, fiber and biofuels without increasing deforestation rates.

The new available land for agricultural production must be managed in a GHG-friendly way, with widespread adoption of best management practices. Moreover, the present areas under agriculture also need to increase productivity while not compromising the GHG emissions, i.e., more productivity with less GHG emission associated to the agrosystem and food supply chains. Thus, Brazil needs a strategic plan to increase fibber, food and biofuel productivity and at the same time reduce emissions associated to these agribusinesses activities. Once this strategic plan is implemented, it would not only promote environment benefits but also aggregate value to the exported bio-products. However, to reach this strategic plan the Government must allocate financial resources and technical support to help producers place Brazil in a better environmental position among other countries. It will be a major challenge, besides promoting those actions, to adequately monitor, report and validate emission reductions from the different sectors.

\section{Acknowledgements}

Research works that lead to this publication was supported partly by grants and fellowships from CNPq, FAPESP, CAPES/COFECUB.

\section{References}

Associação Brasileira de Produtores de Florestas Plantadas [ABRAF]. 2007. ABRAF Statistical Yearbook 2007: Base year 2006. ABRAF, Brasilia, DF, Brazil. 80p. Associação Brasileira de Produtores de Florestas Plantadas [ABRAF]. 2008. ABRAF Statistical Yearbook 2008: Base year 2007. ABRAF, Brasilia, DF, Brazil. 90p. Associação Brasileira de Produtores de Florestas Plantadas [ABRAF]. 2009. ABRAF Statistical Yearbook 2009: Base year 2008. ABRAF, Brasilia, DF, Brazil. 31p.

Bayer, C.; Martin-Neto, L.; Mielniczuk, J.; Pavinato, A.; Dieckow, J. 2006. Carbon sequestration in two Brazilian Cerrado soils under no-till. Soil \& Tillage Research 86: 237-245.

Bernoux, M.; Carvalho, M.C.S.; Volkoff, B.; Cerri, C.C. 2001. CO emission from mineral soils following land-cover change in Brazil. Global Change Biology 7: 779-787.

Bernoux, M.; Carvalho, M.C.S.; Volkoff, B.; Cerri, C.C. 2002. Brazil's soil carbon stocks. Soil Science Society of America Journal 66: 888-896.

Bernoux, M; Cerri, C.C.; Cerri, C.E.P.; Siqueira Neto, M.; Metay, A.; Perrin, A.S.; Scopel, E.; Razafimbelo, T.; Blavet, D.; Piccolo, M.C.; Pavei, M.; Milne, E. 2006. Cropping systems, carbon sequestration and erosion in Brazil, a review. Agronomy for Sustainable Development 26: 1-8.

Bernoux, M.; Branca, G.; Carro, A.; Lipper, L.; Smith, G.; Bockel, L. 2010. Proposal for ex-ante greenhouse gas balance of agriculture and forestry development programs: EX-ACT (EXAnte Carbon-Balance Tool). Scientia Agricola 67: 31-40.

Brasil. Lei ${ }^{\circ}$. 11.097, de 13 de janeiro de 2005. Available at: http:/ /www.mct.gov.br/legis/leis/11097_2005.htm [Accessed Jul. 17, 2005].

Brasil. Ministério de Minas e Energia. 2006. Emissões de Metano do Cultivo de Arroz. In: Primeiro Inventário Brasileiro de Emissões Antrópicas de Gases do Efeito Estufa. Relatório de referência. Ministério de Minas e Energia, Brasília, DF, Brazil.

Brasil. Ministério de Minas e Energia. 2007. .Plano Nacional de Energia 2030. Ministério de Minas e Energia, Brasília, DF, Brazil. 12v.

Brasil. Governo Federal - Comitê Interministerial sobre Mudança do Clima. Plano Nacional sobre Mudança do Clima (PNMC). 2008a. Governo Federal, Brasília, DF, Brazil. 132p. Available at: http://www.forumclima.org.br/arquivos/plano-nacionalmc.pdf [Accessed Jan. 11, 2009]

Brasil. Ministério da Agricultura e Pecuária. 2008b. Projeções do Agronegócio Mundial e Brasil 2006/2007 - 2017/2018. Relatório de referência. Ministério da Agricultura e Pecuária e Abastecimento, Brasília, DF, Brazil. 58p.

Brasil. Ministry of Science and Technology. General Coordination on Global Climate Change. 2004. Brazil's Initial National Communication to the United Nations Framework Convention on Climate Change. Ministério da Ciência e Tecnologia, Brasília, DF, Brazil. 271p.

Carvalho, J.L.N.; Cerri, C.E.P.; Feigl, B.J.; Piccolo, M.C.; Godinho, V.P.; Cerri, C.C. 2009. Carbon sequestration in agricultural soils in the Cerrado region of the Brazilian Amazon. Soil \& Tillage Research 103: 342-349.

Cerri, C.C.; Bernoux, M.; Cerri, C.E.P.; Feller, C. 2004. Carbon cycling and sequestration opportunities in South America: The case of Brazil. Soil Use and Management 20: 248-254.

Cerri, C.C.; Maia, S.M.F.; Galdos, M.V.; Cerri, C.E.P.; Feigl, B.J.; Bernoux, M. 2009. Brazilian greenhouse gas emissions: the importance of agriculture and livestock. Scientia Agricola 66: 831-843.

Cerri, C.E.P.; Sparovek, G.; Bernoux, M.; Easterling, W.E.; Melillo, J.M.; Cerri, C.C. 2007. Tropical agriculture and global warming: impacts and mitigation options. Scientia Agricola 64: 83-89.

Coelho, S.T.; Bolognini, M.F.; Paletta, C.E.M. 2000. Proalcool: The Brazilian Alcohol Program. Green Times 7: 1-2.

Companhia Nacional de Abastecimento [CONAB]. 2009. Companhia Nacional de Abastecimento. Available at: http:// www.conab.gov.br. [Accessed Oct. 25, 2009] 
Demarchi, J.J.A.A.; Manella, M.Q.; Lourenço, A.J.; Alleoni, G.F.; Frighetto, R.T.S.; Primavesi, O.; Lima, M.A. 2003. Preliminary results on methane emission by Nelore cattle in Brazil grazing Brachiaria brizantha cv. Marandu. International Methane and Nitrous Oxide Mitigation Conference 3. Beijing, China, 5p. Available at: http://www.coalinfo.net.cn/coalbed/meeting/ 2203/papers/agriculture/AG011.pdf [Accessed May 08, 2007]

Empresa Brasileira de Pesquisa Agropecuária [EMBRAPA]. 2009. Zoneamento agroecológico da cana-de-açucar. In: Manzatto, C.V. Embrapa Solos, Rio de Janeiro, RJ, Brazil. 55p.

Food and Agriculture Organization [FAO]. 2006. Livestock's long shadow: environmental issues and options. FAO, Rome. p.408.

Galdos, M.V.; Cerri, C.C.; Cerri, C.E.P. 2009. Soil carbon stocks under burned and unburned sugarcane in Brazil. Geoderma 153: $347-352$

Gomes, J. 2006. Emissão de gases do efeito estufa e mitigação do potencial de aquecimento global por sistemas conservacionistas de manejo do solo. Dr. Thesis, - Universidade Federal do Rio Grande do Sul, Porto Alegre, RS, Brazil. 151p.

Gonçalves, J.L.M. 1995. Recomendações de adubação para Eucalyptus, Pinus e espécies típicas da Mata Atlântica. Documentos Florestais 15: 1-23.

Graboski, M.S.; McCormick, R.L. 1998. Combustion of fat and vegetable oil derived fuels in diesel engines. Progress in Energy and Combustion Science. 24: 125-164.

Instituto Brasileiro de Geografia e Estatística [IBGE]. 2008. Levantamento Sistemático da Produção Agrícola. IBGE, Rio de Janeiro, RJ, Brazil.

Intergovernmental Panel on Climate Change [IPCC]. 1997 IPCC Guidelines for National Greenhouse Gas Inventories: Reporting Instructions; Workbook; Reference Manual. IPPC, Paris, FR. $3 \mathrm{v}$.

Intergovernmental Panel on Climate Change [IPCC]. 2006 IPCC Guidelines for National Greenhouse Gas Inventories: Agriculture, Forestry and Other Land Use. Institute for Global Environmental Strategies, Tokio, Japan. v.4, 644p.

Intergovernmental Panel on Climate Change [IPCC]. 2007. United Nations Environment Programme. Assessment report 4; Contribution of Working Groups I, II and III to the Fourth Assessment Report of the Intergovernmental Panel on Climate Change. IPPC, Geneva, CH.

Macedo, I.C.; Seabra J.E.A. 2008. In Sugarcane ethanol: Contributions to climate change mitigation and the environment. Zuurbier, P.; Van de Vooren, J., eds. Sugarcane ethanol: Contribution to climate change mitigation and the environment Wageningen Academic, Wageningen, NL. chap.4.

Macedo, I.C.; SEABRA, J.E.A.; SILVA, J.E.A.R. 2008. Green house gases emissions in the production and use of ethanol from sugarcane in Brazil: The 2005/2006 averages and a prediction for 2020. Biomass and Bioenergy 32: 582-595.

Mafra, A.L.; Guedes, S.F.F.; Klauberg Filho, O.; Santos, J.C.P.; Almeida, J.A.; Rosa, J.D. 2008. Carbono orgânico e atributos químicos do solo em áreas florestais. Revista Árvore 32: $217-$ 224.
Mangino, J.; Bartram, D; Brazy, A. 2001. Development of a methane conversion factor to estimate emissions from animal waste lagoons. U.S. EPA's 17th Annual Emission Inventory Conference, Atlanta GA, USA.

Pedreira, M.S.; Primavesi, O.; Lima, M.A.; Frighetto, R.; Oliveira, S.G.; Berchielli, T.T. 2009. Ruminal methane emission by dairy cattle in Southeast Brazil. Scientia Agricola 66: 742-750.

Programa Nacional de Produção e Uso de Biodiesel [PNPB]. 2004. O Biodiesel. Ministério da Ciência de Tecnologia. Available at: http://www.biodiesel.gov.br [Accessed Apr. 28, 2005].

Rede Baiana de Biocombustíveis [RBB]. 2006. Informativo $\mathrm{n}^{\circ} 119$. Available at: $\mathrm{www}$.redebaianadebiocombustiveis.ba.gov.br [Accessed Jan. 27, 2009].

Reid, R.S.; Thornton, P.K.; McCrabb, G.J.; Kruska, R.L.; Atieno, F.; Jones, P.G. 2004. Is it possible to mitigate greenhouse gas emissions in pastoral ecosystems of the tropics? Environment, Development and Sustainability 6: 91-109.

Salton, J. C. 2005. Matéria orgânica e agregação do solo na rotação lavoura-pastagem em ambiente tropical. Dr. Thesis. Faculdade de Agronomia/ Universidade Federal do Rio Grande do Sul, Porto Alegre, RS, Brazil. 58p.

Sass, R.L.; Fisher, F.M.; Wung, Y.B.; Turner, F.T.; Jund, M.F. 1992. Methane emission from rice fields: the effect of flood water management. Global Biogeochemical Cycles 6: 249-262.

Siqueira Neto, M. 2006. Estoque de carbono e nitrogênio do solo com diferentes usos no Cerrado em Rio Verde (GO). 2006. Dr. Thesis. Centro de Energia Nuclear na Agricultura/Universidade de São Paulo, Piracicaba, SP, Brazil. 162p.

Snyder, C.S.; Bruulsema, T.W.; Jensen, T.L.; Fixen, P.E. 2009. Review of greenhouse gas emissions from crop production systems and fertilizer management effects. Agriculture, Ecosystems and Environment 133: 247-266.

U.S. Environmental Protection Agency [USEPA]. 2006. Global Anthropogenic Non-CO2 Greenhouse Gas Emissions: 19902020. USEPA, Washington, DC, USA. Available at: http:// www.epa.gov/climatechange/economics/international.html [Accessed Sept. 24, 2008]

União da Indústria de Cana-de-Açúcar [UNICA]. 2009. Available at: http://www.unica.com.br [Accessed Oct. 18, 2009].

Votorantim Celulose e Papel [VPC]. 2008. Relatório: Inventário de Gases do Efeito Estufa. VCP Unidade Jacareí Florestal. Available at: http://www.vcp.com.br/SalaImprensa/Noticias/ Documents/VCP_Jacarei_RelatorioInventario_v\%203_0810 31_revisado\%20\%20Auditad̄o_v4.pdf [Accessed Oct. 31, 2008].

Yagi, K.; Tsuruta, K.K.; Minami, K. 1996. Automated monitoring of methane emission from a rice paddy field: the effect of water management. Global Biogeochemical Cycles 10: 255-267.

Zanatta, J.A. 2005. Qualidade dos sistemas de manejo e seu potencial para reter C no solo. MSc. Dissertation. Universidade Federal do Rio Grande do Sul, Porto Alegre, RS, Brazil. 111p.

Received September 23, 2009

Accepted December 02, 2009 